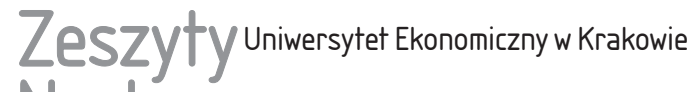 Naukowe
}

10(934)

ISSN 1898-6447

Zesz. Nauk. UEK, 2014; 10 (934): 65-80 DOI: 10.15678/ZNUEK.2014.0934.1005

Katarzyna Kochaniak

Katedra Finansów

Uniwersytet Ekonomiczny w Krakowie

\section{Rola depozytów gospodarstw domowych w stabilizowaniu finansowania instytucji kredytowych strefy euro}

\section{Streszczenie}

W opracowaniu zaprezentowano wyniki badań nas stabilnością depozytów gospodarstw domowych lokowanych w monetarnych instytucjach finansowych 16 krajów tzw. strefy euro. Jego celem jest ocena możliwości regulowania płynności podmiotów za pomocą jednolitych wspólnotowych rozwiązań (norm LCR i NSFR). Przedstawiono różnice w potencjale społeczeństw w zakresie kumulowania depozytów gwarantujących w opinii regulatora stabilność finansowania instytucji w warunkach zarówno normalnych, jak i skrajnych. Badano także przestrzenne zróżnicowanie preferencji gospodarstw domowych dotyczących terminu lokowania środków w zmiennych warunkach gospodarczych i finansowych. Wskazano siłę oddziaływania poszczególnych faz kryzysu finansowego na zmiany w wartościach gromadzonych w MIF depozytów.

Słowa kluczowe: depozyty gospodarstw domowych, depozyty detaliczne, instytucje kredytowe, monetarne instytucje finansowe, normy płynności, LCR, NSFR.

\section{Wprowadzenie}

Zapoczątkowany w 2007 r. globalny kryzys finansowy zweryfikował stanowisko władz nadzorczych w zakresie kształtowania optymalnej struktury 
finansowania instytucji kredytowych ${ }^{1}$. Okazało się bowiem, że dostęp do długookresowych, zdywersyfikowanych i niewrażliwych na zmieniające się otoczenie funduszy zapewniał bezpieczeństwo podmiotów. W nowych, obligatoryjnych regulacjach płynnościowych ${ }^{2}$ pakietu CRD IV/CRR ${ }^{3}$ szczególną uwagę zwrócono na depozyty gospodarstw domowych, akcentując ich stabilny charakter zarówno w warunkach normalnych, jak i skrajnych.

Praca dotyczy stabilności depozytów gospodarstw domowych lokowanych w monetarnych instytucjach finansowych ${ }^{4}$ w latach 2006-2012 w 16 krajach, które przyjęły wspólną walutę. Sformułowano w niej następującą hipotezę badawczą: na wartość oraz zmienność depozytów gospodarstw domowych oddziałują lokalne (narodowe) czynniki, które powinny zostać uwzględnione we wspólnotowych normach płynności dla instytucji kredytowych.

Jej celem jest zatem ocena stabilności depozytów, a także siły oddziaływania otoczenia na wartość analizowanej zmiennej w poszczególnych krajach. Państwa EUGiW, tj.: Austria, Belgia, Cypr, Finlandia, Francja, Grecja, Hiszpania, Holandia, Irlandia, Luksemburg, Malta, Niemcy, Portugalia, Słowacja, Słowenia i Włochy, pozostają zróżnicowane w wielowymiarowej przestrzeni cech charakteryzujących m.in.: poziom rozwoju gospodarczego, lokalne warunki na rynku finansowym, wrażliwość na destabilizację czy kondycję sektora finansów publicznych. Te naro-

${ }^{1}$ Pojęcie instytucji kredytowej zdefiniowane zostało w art. 4 Rozporządzenia Parlamentu Europejskiego i Rady (UE) nr 575/2013 z dnia 26 czerwca 2013 r. w sprawie wymogów ostrożnościowych dla instytucji kredytowych i firm inwestycyjnych, zmieniającego rozporządzenie (UE) nr 648/2012, Dz. UE L 176, 27.06.2013, s. 338-436.

2 Adekwatność struktury finansowania instytucji kredytowych oparto na instrumentach stabilnych zarówno w warunkach normalnych, jak i skrajnych. Zaliczono do nich depozyty gospodarstw domowych, stanowiące ważną część depozytów detalicznych. Znaczenie depozytów ludności dla bezpieczeństwa instytucji kredytowych w krótkim oraz długim okresie zostało zaakcentowane w obligatoryjnych normach płynności - Liquidity Coverage Ratio (LCR) i Net Stable Funding Ratio (NSFR).

${ }^{3}$ Pakiet CRDIV/CRR składa się z: Dyrektywy Parlamentu Europejskiego i Rady 2013/36/ UE z dnia 26 czerwca 2013 r. w sprawie warunków dopuszczenia instytucji kredytowych do działalności oraz nadzoru ostrożnościowego nad instytucjami kredytowymi i firmami inwestycyjnymi, zmieniającej dyrektywę 2002/87/WE i uchylającej dyrektywy 2006/48/WE oraz 2006/49/ WE, Dz. UE L 176, 27.06.2013, s. 1-337; Rozporządzenia Parlamentu Europejskiego i Rady (UE) nr 575/2013 (zawarte w nim rozwiązania regulacyjne opracowane zostały na podstawie porozumień bazylejskich II i III).

${ }^{4}$ Pojęcie monetarnej instytucji finansowej jest szersze od pojęcia instytucji kredytowej. W statystykach EBC za monetarne instytucje finansowe (MIF) uznaje się: instytucje kredytowe i inne instytucje finansowe, których działalność polega na przyjmowaniu depozytów lub środków pieniężnych lokowanych na podobnych warunkach od podmiotów niefinansowych oraz na udzielaniu kredytów i/lub inwestowaniu w papiery wartościowe. Pojęcie to nie obejmuje ESBC. Objęcie badaniami MIF wynika ze struktury bazy danych EBC i braku dostępności szczegółowych informacji liczbowych o depozytach w instytucjach kredytowych. 
dowe uwarunkowania wydają się istotnie oddziaływać na decyzje gospodarstw domowych w zakresie zarządzania ich finansami i tym samym na strukturę finansowania instytucji kredytowych.

Pomimo dynamicznego rozwoju rynku finansowego w okresie przedkryzysowym i bezpośredniego dostępu MIF do finansowania na nim depozyty detaliczne stanowiły w ostatnich latach istotną część sum bilansowych tych podmiotów. W 2012 r., udział najtańszych dla MIF funduszy przekraczał 20\% ogółu zobowiązań w 11 krajach strefy euro: Austrii, Belgii, Cyprze, Grecji, Hiszpanii, Holandii, Niemczech, Portugalii, Słowacji, Słowenii i Włoch. Niższe udziały charakteryzowały sektory: Finlandii, Francji, Irlandii, Luksemburga, Malty i Holandii.

\section{Analiza kształtowania się depozytów gospodarstw domowych w strefie euro}

Charakterystyka depozytów gospodarstw domowych lokowanych w MIF w latach 2006-2012 przeprowadzona została na podstawie zagregowanych wartości zmiennych dla 16 krajów strefy euro. Zbiór objął dane liczbowe nt. depozytów ${ }^{5}$, które udostępnia Europejski Bank Centralny, oraz wielkości populacji państw publikowane przez Eurostat ${ }^{6}$.

W latach 2006-2012 całkowita wartość depozytów gospodarstw domowych lokowanych w MIF w strefie euro ciągle rosła. Najwyższe jej przyrosty odnotowano dla lat: 2008 i 2009 (rys. 1). Były one wywołane istotnymi zmianami warunków ubezpieczenia depozytów w narodowych systemach gwarantowania, które miały zapobiec spadkowi zaufania deponentów do instytucji kredytowych w związku z kryzysem bankowym w Stanach Zjednoczonych.

\footnotetext{
${ }^{5}$ W statystykach Europejskiego Banku Centralnego wyróżnia się następujące kategorie depozytów gospodarstw domowych: terminowe - depozyty z ustalonym terminem zapadalności, które nie mogą być zamienione na gotówkę przed jego nadejściem lub mogą być zamienione na gotówkę przed upływem ustalonego terminu, ale pod warunkiem poniesienia przez deponenta kary umownej; za wypowiedzeniem - depozyty bez uzgodnionego terminu zapadalności, które nie mogą być zamienione na gotówkę bez zachowania okresu wypowiedzenia lub mogą zostać zamienione na gotówkę przed upływem tego okresu, lecz po uiszczeniu przez deponenta kary umownej; overnight - depozyty, które mogą zostać zamienione na gotówkę na żądanie deponenta lub mogą zostać wypłacone za pomocą czeku, polecenia pobrania lub w inny sposób, w tym przez ich transfer na inny rachunek (http://sdw.ecb.europa.eu/browse.do?node=2116082, dostęp: 15.04.2014).
}

${ }^{6}$ http://epp.eurostat.ec.europa.eu (dostęp: 15.04.2014). 


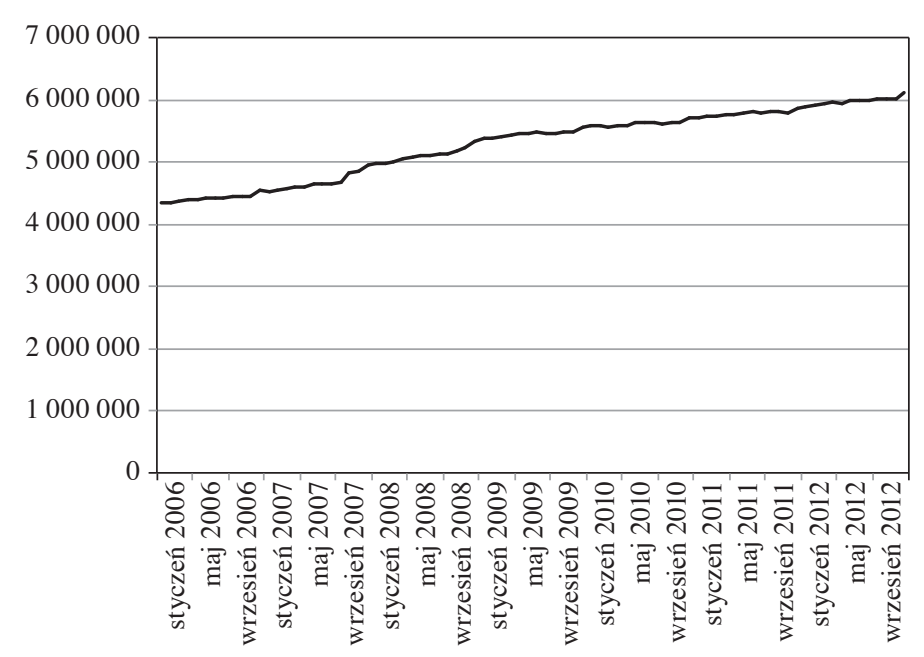

Rys. 1. Depozyty gospodarstw domowych w MIF strefy euro w latach 2006-2012 (mln euro)

Źródło: obliczenia własne na podstawie danych EBC.

Niezależnie od panujących warunków gospodarczych i finansowych całkowita wartość depozytów osób fizycznych w strefie euro pozostawała pod silnym wpływem środków lokowanych przede wszystkim w MIF w: Niemczech, Francji, Włoszech i Hiszpanii ${ }^{7}$. Kraje te wyróżniły się zatem największym potencjałem w zakresie kumulowania depozytów, które w świetle nowych regulacji powinny stanowić stabilne źródło finansowania instytucji kredytowych. W wybranych latach, cechujących się odmiennymi uwarunkowaniami rynku finansowego i gospodarek narodowych, można jednak dostrzec niewielkie zmiany procentowych udziałów wyróżnionych państw.

Ocena skłonności gospodarstw domowych poszczególnych krajów do gromadzenia depozytów w MIF nie jest jednak możliwa bez uwzględnienia różnic w wielkości populacji. Dlatego też wartości depozytów ludności przeliczone zostały na kwoty przypadające na jednego mieszkańca. Statyczna analiza kształtowania się poszczególnych kategorii depozytów gospodarstw domowych w grupie państw strefy

${ }^{7}$ Udział krajowych depozytów gospodarstw domowych w ogólnej wartości depozytów gospodarstw domowych w strefie euro wynosił dla: Niemiec - 30\% w 2012 r., 29\% w 2008 r. i $31 \%$ w 2006 r.; Francji - 19\% w 2012 r., 20\% w 2008 r. i 21\% w 2006 r.; Włoch - 14\% w 2012 r., 13\% w 2008 r. i 11\% w 2006 r.; Hiszpanii - 12\% w 2012 r., 13\% w 2008 r. i 12\% w 2006 r. 
Tabela 1. Charakterystyki liczbowe rozkładu depozytów gospodarstw domowych per capita w strefie euro w latach 2006, 2008 i 2012

\begin{tabular}{|c|c|c|c|c|c|c|c|}
\hline Rok & Opis & $\begin{array}{c}\text { Depozyty } \\
\text { ogółem per } \\
\text { capita }\end{array}$ & $\begin{array}{c}\text { Depozyty } \\
\text { za wypo- } \\
\text { wiedze- } \\
\text { niem do } \\
3 \text { miesięcy } \\
\text { per capita }\end{array}$ & $\begin{array}{c}\text { Depozyty } \\
\text { za wypo- } \\
\text { wiedze- } \\
\text { niem } \\
\text { powyżej } \\
3 \text { miesięcy } \\
\text { per capita }\end{array}$ & $\begin{array}{c}\text { Depozyty } \\
\text { terminowe } \\
\text { do } 2 \text { lat } \\
\text { per capita }\end{array}$ & $\begin{array}{c}\text { Depozyty } \\
\text { terminowe } \\
\text { powyżej } \\
2 \text { lat } \\
\text { per capita }\end{array}$ & $\begin{array}{l}\text { Depozyty } \\
\text { overnight } \\
\text { per capita }\end{array}$ \\
\hline \multirow{4}{*}{2006} & średnia & 18094,2 & 3282,6 & 153,6 & 6275,5 & 1503,0 & 6879,5 \\
\hline & $\min$ & 2706,6 & 0,0 & 0,0 & 396,9 & 21,0 & 1142,8 \\
\hline & maks. & 84536,0 & 15123,0 & 1082,0 & 42413,0 & 5568,0 & 37885,0 \\
\hline & $V_{s}$ & 103,1 & 142,5 & 228,7 & 164,4 & 104,3 & 123,5 \\
\hline \multirow{4}{*}{2008} & średnia & 20059,5 & 3048,1 & 157,0 & 8969,0 & 1154,1 & 6731,2 \\
\hline & $\min$ & 2655,1 & 0,0 & 0,0 & 603,0 & 14,1 & 1273,9 \\
\hline & maks. & 100029,0 & 13892,0 & 1269,0 & 56996,0 & 4069,0 & 38550,0 \\
\hline & $V_{s}$ & 108,4 & 134,4 & 234,6 & 147,9 & 106,6 & 125,8 \\
\hline \multirow{4}{*}{2012} & średnia & 21251,9 & 3749,0 & 146,2 & 6373,5 & 1864,0 & 9119,1 \\
\hline & $\min$. & 3487,4 & 0,0 & 0,0 & 496,4 & 33,0 & 1771,5 \\
\hline & maks. & 87688,0 & 19618,0 & 1162,0 & 26834,0 & 4992,0 & 65144,0 \\
\hline & $V_{s}$ & 89,2 & 157,3 & 217,3 & 111,1 & 81,5 & 161,1 \\
\hline
\end{tabular}

${ }^{a}$ Uwaga: średnią, min. i maks. podano w euro, $V_{s}-\mathrm{w} \%$.

Źródło: obliczenia własne na podstawie danych EBC.

euro w wybranych latach 2006, 2008 i $2012^{8}$ dowodzi ich wysokiego zróżnicowania, wyrażonego współczynnikiem zmienności ${ }^{9}-V_{s}$ (tabela 1). Wskaźnik ten przyjmuje wartości przekraczające $100 \%$ we wszystkich przypadkach z wyjątkiem: depozytów ogółem per capita i depozytów terminowych powyżej 2 lat per capita w 2012 r. Potwierdza on zatem wyraźną niespójność badanych krajów w zakresie kształtowania się depozytów przypadających na jednego mieszkańca. W całej strefie euro gospodarstwa zainteresowane były głównie posiadaniem krótkoterminowych depozytów, niezależnie od panujących warunków finansowych czy gospodarczych. W 2006 r. przeciętna wartość depozytów ogółem przypadająca na mieszkańca wynosiła 18 094,2 euro, stanowiąc sumę głównie: depozytów terminowych do 2 lat (6275,5 euro), overnight (6879,5 euro) i depozytów za wypowiedzeniem do 3 miesięcy (3282,6 euro). W 2008 r. pogorszenie kondycji rynku finansowego i indywidualne podwyższanie

${ }^{8}$ Wskazane lata charakteryzowały odmienne warunki panujące na rynku finansowym i w gospodarkach krajów.

9 Współczynnik zmienności wyrażony jest wzorem: $V_{S}=\frac{\text { odchylenie standardowe }}{\text { średnia arytmetyczna }} \times 100 \%$. 


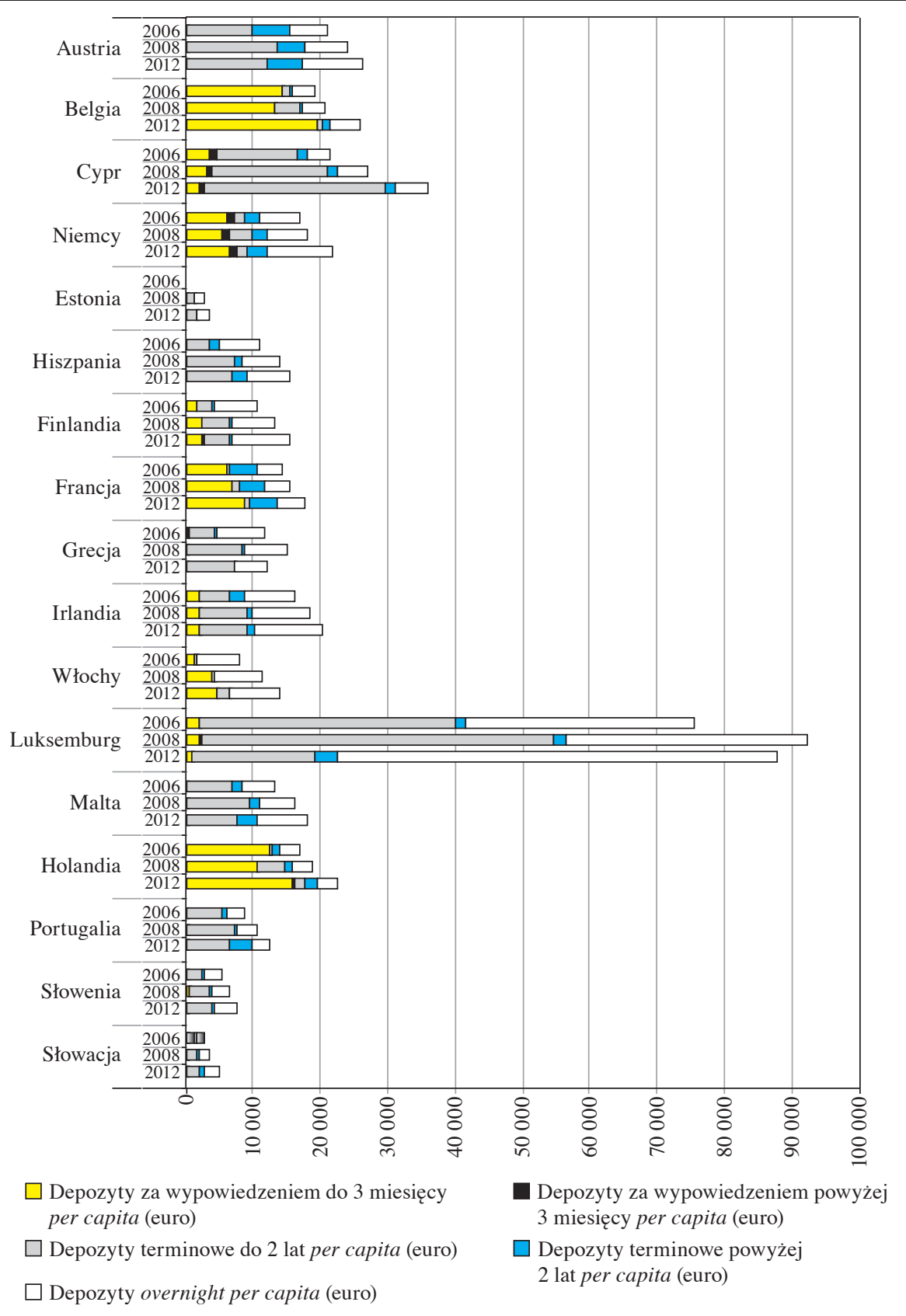

Rys. 2. Wartości i struktura depozytów ogółem gospodarstw domowych per capita w poszczególnych krajach strefy euro w latach 2006, 2008 i 2012 (mln euro) Źródło: obliczenia własne na podstawie danych EBC. 
kwot gwarantowanych depozytów przyczyniło się do wzrostu tej wartości do 20 059,5 euro. Największe zmiany zaobserwowano w podkategorii depozytów terminowych do 2 lat per capita, prowadząc do częściowego zniwelowania różnic między państwami, czego dowodzi niższy poziom współczynnika $V_{s}$. Nieznaczny spadek wartości współczynnika zaobserwowano także dla depozytów za wypowiedzeniem do 3 miesięcy per capita. W ostatnim analizowanym roku średni poziom depozytów ogółem na mieszkańca był wyższy i wyraźnie mniej zróżnicowany w grupie krajów strefy euro niż w 2008 r. Obserwowano jednak skłonność gospodarstw domowych do przesuwania środków lokowanych dotąd na rachunkach lokat terminowych do 2 lat na rachunki kumulujące środki na krótsze okresy, tj. overnight i za wypowiedzeniem do 3 miesięcy. Prowadzi to do wniosku, że gospodarstwa zakładały wówczas możliwość ich wydatkowania lub inwestowania w aktywa finansowe, w szczególności w tych krajach, w których obserwowano ożywienie na rynku finansowym. Wzrost znaczenia depozytów o krótszych terminach zwrotu nie został bowiem potwierdzony we wszystkich państwach. Dowodzą tego współczynniki $V_{s}$, które wykazały wartości wyższe od tych otrzymanych dla $2008 \mathrm{r}$.

Wartości oraz struktura depozytów per capita w poszczególnych krajach strefy euro w latach 2006, 2008 i 2012 (rys. 2) także zwracają uwagę na niejednolitą ich wrażliwość na zmieniające się uwarunkowania makroekonomiczne. W 2006. wyraźnie odbiegały one od tych obserwowanych w latach 2008 i 2012. We wszystkich latach dominowały jednak depozyty krótkoterminowe: overnight, za wypowiedzeniem do 3 miesięcy i terminowe do 2 lat. W 2008 r. kryzys finansowy przyczynił się do wzrostu ogólnej wartości depozytów ludności w bankach, głównie na skutek zainteresowania depozytami terminowymi do 2 lat. Ponadto w krajach wyróżniających się dotąd największymi wartościami depozytów o charakterze długoterminowym, takich jak: Austria, Francja czy Malta, nastąpił wyraźny spadek ich udziału w ogólnych kwotach. Po 4 latach łagodzenia napięć na rynku finansowym w badanych krajach strefy euro, z wyjątkiem Grecji i Luksemburga, zaobserwowano wyższe wartości depozytów ogółem per capita. Ponadto odnotowano wzrost znaczenia depozytów terminowych powyżej 2 lat w: Luksemburgu, Austrii, Holandii, Belgii, Niemczech, Finlandii, Hiszpanii, Portugalii, Grecji, Słowenii i Słowacji oraz na Malcie.

\section{Próba identyfikacji podobieństw pomiędzy krajami strefy euro w zakresie wartości depozytów}

Wielowymiarowe zróżnicowanie państw członkowskich strefy euro skłania do podjęcia próby wyłonienia względnie jednorodnych ich podgrup w zakresie wartości analizowanych kategorii depozytów gospodarstw domowych. Porównując 
diagramy przedstawiające drzewka powiązań dla lat 2006, 2008 i 2012 (rys. 3-5), można dostrzec wyraźne podobieństwa pomiędzy Belgią i Holandią oraz Słowacją i Słowenią, pomimo zmian zachodzących w sytuacji gospodarczej tych państw oraz trudności występujących na rynku finansowym. Ponadto Niemcy i Francja pozostawały w jednej podgrupie we wszystkich analizowanych latach. W $2006 \mathrm{r}$. tworzyły one jeden podzbiór wraz z Belgią i Holandią. Dwa lata później zbiór ten powiększył się jednak o Włochy, a w 2012 r. o Finlandię. Można zatem dostrzec ukierunkowane zmiany zachodzące w depozytach gospodarstw domowych per capita niektórych krajów. Dowodzą one postępującej transformacji strukturalnej strefy euro pod względem kształtowania się wartości depozytów w czasie, jak i utrzymującej się odmienności Luksemburga.

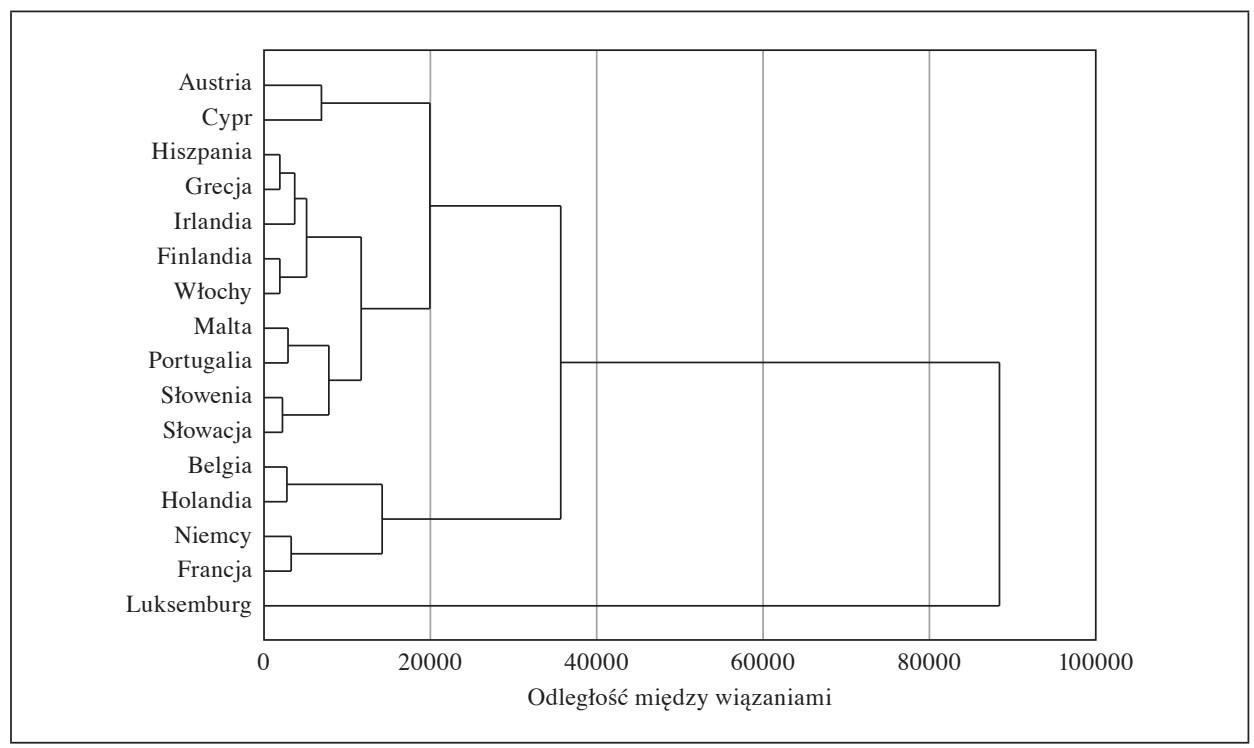

Rys. 3. Drzewko powiązań dla krajów strefy euro w zakresie poziomu depozytów gospodarstw domowych per capita w MIF w $2006 \mathrm{r}$.

Źródło: obliczenia własne na podstawie danych EBC i Eurostatu.

Na podstawie powyższych analiz wskazano różnice w kształtowaniu się opisywanej kategorii depozytów w grupie 16 państw. Zidentyfikowano kraje, w których ewoluująca destabilizacja była dla gospodarstw domowych swoistym bodźcem do posiadania depozytów, oraz kraje, w których pomimo wzmacniania systemów gwarantowania i braku alternatywnych możliwości inwestycyjnych na rynku finansowym ludność zaczęła ograniczać swoje należności od MIF (Luksemburg i Grecja). W przypadku Grecji ta szczególna sytuacja związana była z koniecz- 
nością przeznaczania oszczędności na cele konsumpcyjne ze względu na rosnącą od 2010 r. stopę bezrobocia i pogarszające się warunki życia. W grupie widoczne są także różnice w zakresie struktury depozytów. Można wskazać państwa, w których wraz z upływem czasu zwiększano wartość środków lokowanych na krótsze okresy kosztem tych lokowanych na dłuższe, oraz takie, w których nasilająca się destabilizacja motywowała do interesowania się głównie ofertami lokat długoterminowych i rezygnowania z posiadania pozostałych.

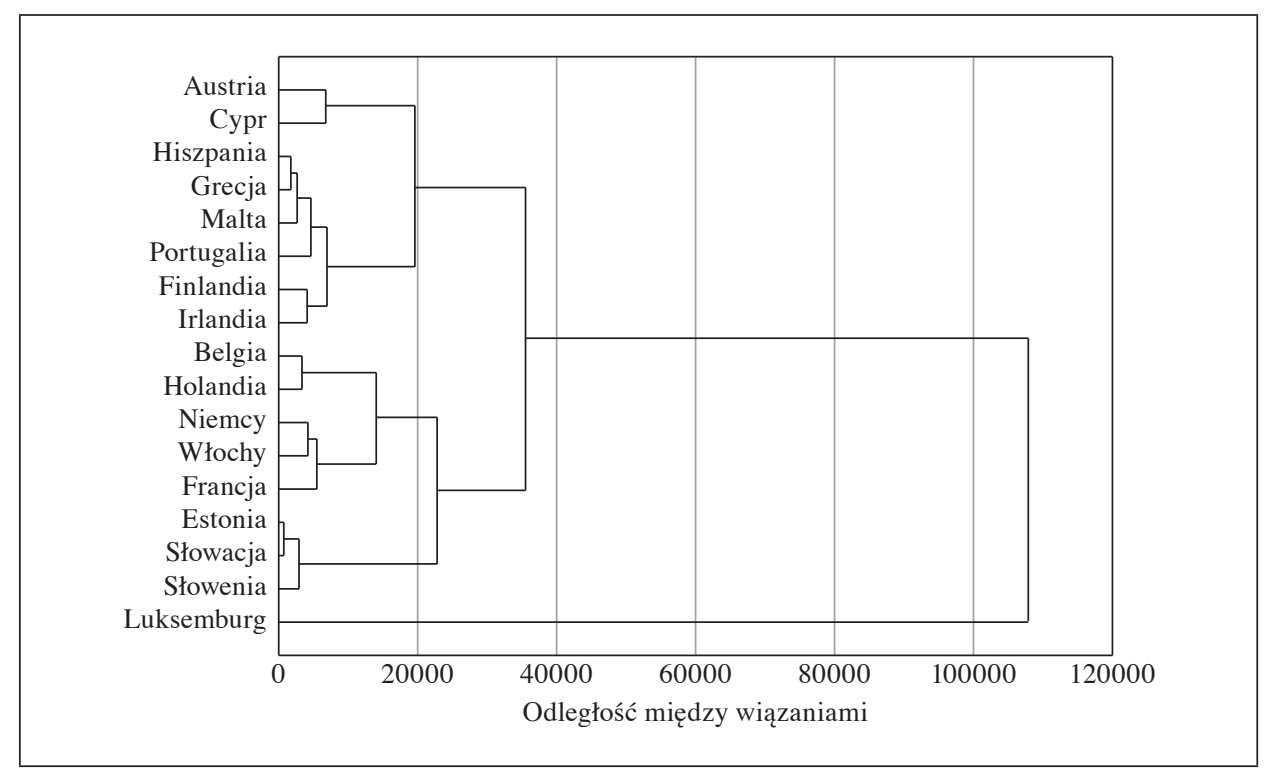

Rys. 4. Drzewko powiązań dla krajów strefy euro w zakresie poziomu depozytów gospodarstw domowych per capita w MIF w 2008 r.

Źródło: obliczenia własne na podstawie danych EBC i Eurostatu.

W tych warunkach istnieją podstawy do podania w wątpliwość zakładanej w normach płynności bezwarunkowej stabilności depozytów gospodarstw domowych. W przypadku gdy utożsamia się ją z niezmiennością, statecznością czy trwałością w czasie, wszelkie istotne zmiany - niezależnie od ich kierunku powinny być przedmiotem obserwacji. W celu zobrazowania różnic dotyczących wrażliwości depozytów na zmiany lat 2006-2012 obliczono wartości współczynników zmienności $V_{s}$ dla poszczególnych krajów (tabela 2). W analizach zjawisk społeczno-ekonomicznych przyjmuje się, że wynik przekraczający $20 \%$ jest tożsamy ze znaczną fluktuacją zmiennej objaśnianej. 


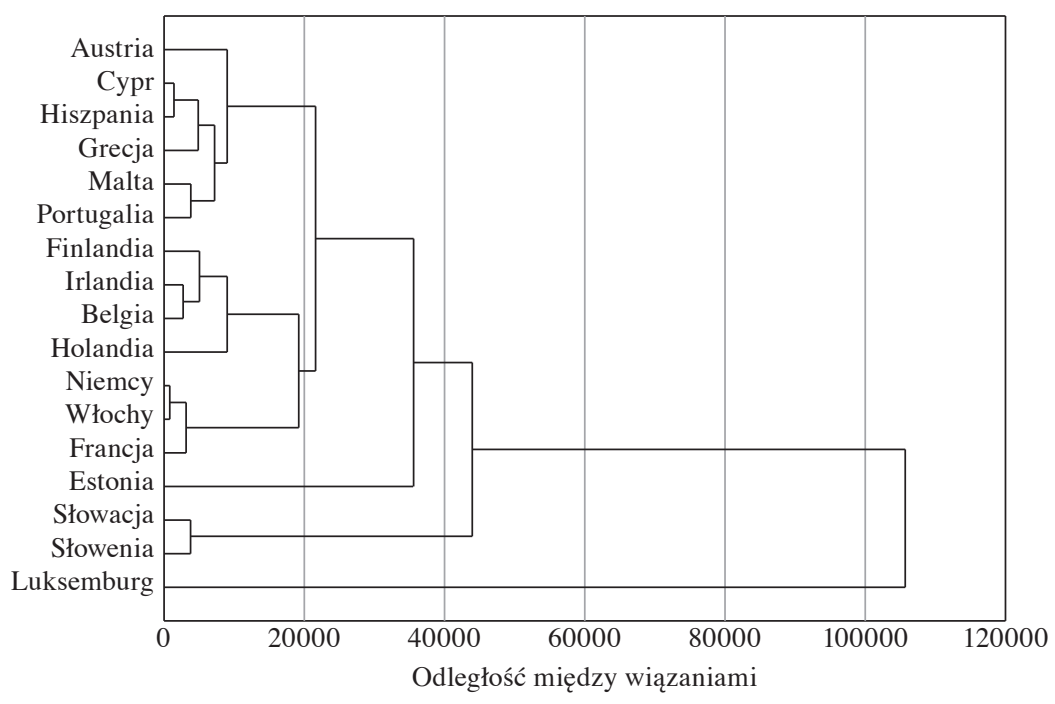

Rys. 5. Drzewko powiązań dla krajów strefy euro w zakresie poziomu depozytów gospodarstw domowych per capita w MIF w 2012 r.

Źródło: obliczenia własne na podstawie danych EBC i Eurostatu.

Tabela 2. Współczynniki zmienności $\left(V_{s}\right)$ dla depozytów ogółem gospodarstw domowych w krajach strefy euro w latach 2006-2012

\begin{tabular}{|l|c|}
\hline \multicolumn{1}{|c|}{ Wyszczególnienie } & $V_{s}$ \\
\hline Austria & 9,41 \\
\hline Belgia & 12,61 \\
\hline Cypr & 17,31 \\
\hline Finlandia & 16,51 \\
\hline Francja & 8,55 \\
\hline Grecja & 16,59 \\
\hline Hiszpania & 15,79 \\
\hline Holandia & 11,97 \\
\hline Irlandia & 13,77 \\
\hline Luksemburg & 5,98 \\
\hline Malta & 11,89 \\
\hline Niemcy & 9,88 \\
\hline Portugalia & 13,65 \\
\hline Słowacja & 19,21 \\
\hline Słowenia & 13,66 \\
\hline Włochy & 22,69 \\
\hline
\end{tabular}

Źródło: obliczenia własne na podstawie danych EBC. 
Miernik wskazał na zróżnicowaną wrażliwość depozytów, która okazała się najsilniejsza: we Włoszech, na Słowacji, na Cyprze, w Grecji i w Finlandii, zaś najsłabsza - w Luksemburgu i w Niemczech. W przypadku Włoch wartość współczynnika przekroczyła przyjętą granicę, informując o znacznej zmienności lokalnych depozytów. Ponieważ ich fluktuację badano w całym siedmioletnim okresie, podjęto próbę ustalenia, w jakich okolicznościach zmiany się nasilały. W tym celu wyodrębniono następujące podokresy:

- P1: I-III kw. 2007 r. (okres przedkryzysowy),

- P2: IV kw. 2007 r. - III kw. 2008 r. (okres kryzysu w USA, do upadku Lehman Brothers Holdings Inc.),

- P3: IV kw. 2008 r. - IV kw. 2010 r. (okres kryzysu po upadku Lehman Brothers Holdings Inc., do wypełnienia przez kraje członkowskie Unii Europejskiej obowiązku ustanowienia wyższego limitu gwarantowanych depozytów, wynoszącego 100 tys. euro);

- P4: I kw. 2011 r. - IV kw. 2012 r. (okres kryzysu zadłużenia publicznego i rosnącej destabilizacji gospodarczej).

Za podstawę porównania przyjęto P0 (I-IV kw. 2006 r.), utożsamiany z okresem względnego rozwoju.

Analizę przeprowadzono dla wybranych krajów: reprezentujących wyłonione podgrupy (Niemcy, Słowacja i Holandia) oraz szczególnych, indywidualnych przypadków (Portugalia, Hiszpania, Grecja i Luksemburg).

Na podstawie modeli dynamicznych podjęto próbę określenia różnic w kształtowaniu się ogólnego poziomu depozytów gospodarstw domowych w warunkach zmiennego otoczenia, wprowadzając wyodrębnione podokresy jako zmienne objaśniające.

Zaproponowano następujące ich postaci [Statystyka... 2004, Pociecha i in. 1988, Maddala 2007]:

- liniową:

- wykładniczą:

$$
y_{i}=\alpha_{0}+\sum_{j=1}^{4} \alpha_{j} P_{i j}+\varepsilon_{i}
$$

$$
y_{i}=e^{\left(\alpha_{0}+\sum_{j=1}^{4} \alpha_{j} P_{i j}+\varepsilon_{i}\right)},
$$

którą po zlogarytmowaniu zapisano wzorem:

gdzie:

$$
\ln y_{i}=\alpha_{0}+\sum_{j=1}^{4} \alpha_{j} P_{i j}+\varepsilon_{i}
$$

$P_{i j}$ - przynależność $i$-tego kwartału do $j$-tego podokresu $(j=1,2,3,4)$. Podstawę porównania stanowi podokres P0 (I-IV kw. 2006 r.),

$y_{i}$-zaobserwowane wartości depozytów w $i$-tym kwartale $(i=1,2, \ldots, 24)$,

$\varepsilon_{i}-$ reszty równania. 
W przypadku Niemiec najlepsze pod względem statystycznym dopasowanie modelu otrzymano dla postaci wykładniczej (tabela 3). Wyjaśnił on $94 \%$ zmienności depozytów ogółem w latach 2006-2012. Wszystkie podokresy (P1-P4) okazały się statystycznie istotne, ale największe zmiany w wartości zmiennej objaśnianej odnotowano w podokresie P4. Była ona wyższa średnio o 25,9\% od poziomu depozytów w okresie względnej stabilności, który stanowił podstawę porównania ${ }^{10}$. Nieco mniejszy wpływ na poziom depozytów miał okres P3 i zaistniałe wówczas wydarzenia. Kolejność oddziaływania zmiennych czasowych skłania do stwierdzenia, że ewolucja i pogłębianie się zaburzeń w otoczeniu stanowiły dla gospodarstw domowych w Niemczech istotny bodziec do gromadzenia nadwyżkowych środków na rachunkach w MIF.

Tabela 3. Oceny parametrów modelu wykładniczego dla depozytów gospodarstw domowych ogółem w Niemczech w okresie od I kw. 2006 r. do IV kw. 2012 r.

\begin{tabular}{|l|c|c|c|c|c|c|}
\hline Wyszczególnienie & Alfa & Błąd st. & $A$ & Błąd st. & $t(24)$ & Poziom $p$ \\
\hline Wyraz wolny & $\mathrm{x}$ & $\mathrm{x}$ & 14,14 & 0,01 & 1282,37 & 0,000000 \\
\hline P4 & 1,20 & 0,07 & 0,23 & 0,01 & 17,20 & 0,000000 \\
\hline P3 & 0,80 & 0,07 & 0,15 & 0,01 & 11,31 & 0,000000 \\
\hline P2 & 0,26 & 0,06 & 0,06 & 0,01 & 3,99 & 0,000573 \\
\hline P1 & 0,06 & 0,06 & 0,02 & 0,02 & 1,04 & 0,307990 \\
\hline \multicolumn{7}{|c|}{$F(3,24)=104,85 ; R^{2}=0,94 ; s_{\varepsilon}=0,02$} \\
\hline
\end{tabular}

Źródło: obliczenia własne na podstawie danych EBC.

Podobne wnioski można sformułować w odniesieniu do depozytów gospodarstw domowych w Holandii (tabela 4). W modelu regresji liniowej wystąpiły trzy statystycznie istotne zmienne czasowe. Zmienna zależna istotnie zwiększała się wraz z postępującą destabilizacją, począwszy od podokresu P2. Faza poprzedzająca kryzys finansowy w strefie euro, z symptomami zbliżającej się nierównowagi, okazała się statystycznie nieistotna. Równanie wyjaśniło $93 \%$ zmienności depozytów ogółem.

Jak wykazano w tabeli 5, największe zmiany w depozytach lokowanych w Luksemburgu w stosunku do okresu stanowiącego podstawę porównania wystąpiły w okresie P2. Dwa ostatnie podokresy w zbliżonym stopniu oddziaływały na wartość analizowanej zmiennej, która była wyższa średnio o ponad 5 mld euro od wartości charakteryzującej okres będący podstawą porównania. Należy zauważyć, iż w tej części analizy, przy tak zdefiniowanych przedziałach czasowych, nie ujawnił się spadek wartości depozytów, który odnotowano pod

$10\left(e^{0,23}-1\right) \cdot 100 \%=25,9 \%$. 
koniec 2012 r. Doprowadził on wówczas do ukształtowania się wartości zmiennej objaśnianej na poziomie niższym niż odnotowany pod koniec 2008 r.

Tabela 4. Oceny parametrów modelu liniowego dla depozytów gospodarstw domowych ogółem w Holandii w okresie od I kw. 2006 r. do IV kw. 2012 r.

\begin{tabular}{|l|c|c|c|c|c|c|}
\hline Wyszczególnienie & Alfa & Błąd st. & $A$ & Błąd st. & $t(24)$ & Poziom $p$ \\
\hline Wyraz wolny & $\mathrm{x}$ & $\mathrm{x}$ & 282141,20 & 4895,33 & 57,63 & 0,000000 \\
\hline P4 & 1,23 & 0,08 & 90463,40 & 5995,52 & 15,09 & 0,000000 \\
\hline P3 & 0,85 & 0,08 & 60909,30 & 5883,40 & 10,35 & 0,000000 \\
\hline P2 & 0,32 & 0,08 & 28044,40 & 6567,77 & 4,27 & 0,000287 \\
\hline \multicolumn{7}{|c|}{$F(4,24)=75,47 ; R^{2}=0,93 ; s_{\varepsilon}=9790,6$} \\
\hline
\end{tabular}

Źródło: obliczenia własne na podstawie danych EBC.

Tabela 5. Oceny parametrów modelu liniowego dla depozytów gospodarstw domowych ogółem w Luksemburgu w okresie od I kw. 2006 r. do IV kw. 2012 r.

\begin{tabular}{|l|c|c|c|c|c|c|}
\hline Wyszczególnienie & Alfa & Błąd st. & $A$ & Błąd st. & $t(24)$ & Poziom $p$ \\
\hline Wyraz wolny & $\mathrm{x}$ & $\mathrm{x}$ & 39844,00 & 721,91 & 55,19 & 0,000000 \\
\hline P2 & 1,11 & 0,15 & 7295,40 & 968,55 & 7,53 & 0,000000 \\
\hline P4 & 0,96 & 0,16 & 5385,50 & 884,16 & 6,09 & 0,000003 \\
\hline P3 & 0,96 & 0,16 & 5186,00 & 867,63 & 5,98 & 0,000004 \\
\hline P1 & 0,37 & 0,13 & 3627,00 & 1250.39 & 2,90 & 0,008059 \\
\hline \multicolumn{7}{|c|}{$F(3,24)=15,60 ; R^{2}=0,73 ; s_{\varepsilon}=1443,8$} \\
\hline
\end{tabular}

Źródło: obliczenia własne na podstawie danych EBC.

Tabela 6. Oceny parametrów modelu liniowego dla depozytów gospodarstw domowych ogółem w Hiszpanii w okresie od I kw. 2006 r. do IV kw. 2012 r.

\begin{tabular}{|l|c|c|c|c|c|c|}
\hline Wyszczególnienie & Alfa & Błąd st. & $A$ & Błąd st. & $t(24)$ & Poziom $p$ \\
\hline Wyraz wolny & $\mathrm{x}$ & $\mathrm{x}$ & 518253,2 & 9853,52 & 52,60 & 0,000000 \\
\hline P4 & 1,24 & 0,07 & 212198,1 & 12068,04 & 17,58 & 0,000000 \\
\hline P3 & 1,13 & 0,07 & 187285,6 & 11842,45 & 15,81 & 0,000000 \\
\hline P2 & 0,55 & 0,07 & 111114,6 & 13219,88 & 8,41 & 0,000000 \\
\hline P1 & 0,18 & 0,06 & 54966,8 & 17066,79 & 3,22 & 0,003787 \\
\hline \multicolumn{7}{|c|}{$F(3,24)=101,88 ; R^{2}=0,95 ; s_{\varepsilon}=19707,00$} \\
\hline
\end{tabular}

Źródło: obliczenia własne na podstawie danych EBC.

W przypadku Hiszpanii wszystkie zmienne czasowe statystycznie istotnie oddziaływały na kształtowanie się zmiennej objaśnianej (tabela 6). Siła wpływu podokresów zwiększała się wraz z ewolucją destabilizacji. W okresie kryzysu 
zadłużenia sektora publicznego wartość zgromadzonych w MIF depozytów była wyższa średnio o $212198,1 \mathrm{mln}$ euro od poziomu charakteryzującego okres względnego rozwoju. Powyższy model pozwolił na wyjaśnienie $95 \%$ zmienności analizowanego zjawiska. W Portugalii wpływ koniunktury panującej na rynku finansowym ujawnił się dopiero w okresie P2 i nasilał w kolejnych podokresach (tabela 7). Wartość depozytów gospodarstw domowych w okresie P2 była wyższa od poziomu charakteryzującego okres będący podstawą porównania o ok. 12 mld euro, w podokresie P3 - o ok. 24 mld euro, zaś w P4 - o ok. 36 mld euro. Podobnie jak w równaniu dla depozytów w Hiszpanii wyjaśnionych zostało 95\% zmienności wartości depozytów gospodarstw domowych.

Tabela 7. Oceny parametrów modelu liniowego dla depozytów gospodarstw domowych ogółem w Portugalii w okresie od I kw. 2006 r. do IV kw. 2012 r.

\begin{tabular}{|l|c|c|c|c|c|c|}
\hline Wyszczególnienie & Alfa & Błąd st. & $A$ & Błąd st. & $t(24)$ & Poziom $p$ \\
\hline Wyraz wolny & $\mathrm{x}$ & $\mathrm{x}$ & 93398,67 & 1335,44 & 69,94 & 0,000000 \\
\hline P4 & 1,19 & 0,06 & 36456,21 & 1766,62 & 20,64 & 0,000000 \\
\hline P3 & 0,83 & 0,06 & 24562,33 & 1724,04 & 14,25 & 0,000000 \\
\hline P2 & 0,33 & 0,05 & 11859,33 & 1980,78 & 5,99 & 0,000004 \\
\hline \multicolumn{7}{|c|}{$F(3,24)=158,25 ; R^{2}=0,95 ; s_{\varepsilon}=3271,10$} \\
\hline
\end{tabular}

Źródło: obliczenia własne na podstawie danych EBC.

W modelu liniowym dla Słowacji wyjaśniono 97\% zmienności wartości depozytów ogółem i wskazano na istotność oddziaływania wszystkich zmiennych czasowych (tabela 8). Powtórzyła się obserwowana w części krajów prawidłowość nasilającego się z czasem wpływu otoczenia na zmienną objaśnianą.

Tabela 8. Oceny parametrów modelu liniowego dla depozytów gospodarstw domowych ogółem w Słowacji w okresie od I kw. 2006 r. do IV kw. 2012 r.

\begin{tabular}{|l|c|c|c|c|c|c|}
\hline Wyszczególnienie & Alfa & Błąd st. & $A$ & Błąd st. & $t(24)$ & Poziom $p$ \\
\hline Wyraz wolny & $\mathrm{x}$ & $\mathrm{x}$ & 14885,00 & 378,19 & 39,36 & 0,000000 \\
\hline P4 & 1,21 & 0,05 & 10432,00 & 463,19 & 22,52 & 0,000000 \\
\hline P3 & 0,95 & 0,05 & 7900,33 & 454,53 & 17,38 & 0,000000 \\
\hline P2 & 0,33 & 0,05 & 3309,00 & 507,40 & 6,52 & 0,000001 \\
\hline P1 & 0,09 & 0,04 & 1429,00 & 655,05 & 2,18 & 0,039621 \\
\hline \multicolumn{7}{|c|}{$F(3,24)=179,32 ; R^{2}=0,97 ; s_{\varepsilon}=756,38$} \\
\hline
\end{tabular}

Źródło: obliczenia własne na podstawie danych EBC. 
Tabela 9. Oceny parametrów modelu liniowego dla depozytów gospodarstw domowych ogółem w Grecji w okresie od I kw. 2006 r. do IV kw. 2012 r.

\begin{tabular}{|l|c|c|c|c|c|c|}
\hline Wyszczególnienie & Alfa & Błąd st. & $A$ & Błąd st. & $t(24)$ & Poziom $p$ \\
\hline Wyraz wolny & $\mathrm{x}$ & $\mathrm{x}$ & 134674,00 & 5011,98 & 26,87 & 0,000000 \\
\hline P3 & 1,10 & 0,13 & 52950,60 & 6023,65 & 8,79 & 0,000000 \\
\hline P2 & 0,49 & 0,11 & 28587,00 & 6724,27 & 4,25 & 0,000301 \\
\hline \multicolumn{7}{|c|}{$F(3,24)=29,23 ; R^{2}=0,84 ; s_{\varepsilon}=10024,00$} \\
\hline
\end{tabular}

Źródło: obliczenia własne na podstawie danych EBC.

Wyniki uzyskane dla Grecji nie potwierdziły statystycznie istotnego wpływu warunków podokresu P4 na poziom depozytów ogółem (tabela 9). Należy jednak pamiętać, że nastąpiło wówczas wyraźne zmniejszenie ogólnej wartości depozytów gospodarstw domowych w MIF (rys. 2). Model pozwolił na wyjaśnienie 84\% zmienności depozytów za pomocą dwóch statystycznie istotnych zmiennych objaśniających - P3 i P2. W czasie kryzysu bankowego i interwencji mających na celu przywrócenie równowagi przeciętna wartość depozytów gospodarstw domowych przewyższała poziom charakteryzujący okres będący podstawą porównania.

\section{Podsumowanie}

Badanie depozytów gospodarstw domowych per capita w 16 krajach członkowskich EUGiW wskazało na występowanie różnic w mechanizmach ich kształtowania w wybranych latach. W pracy dowiedziono istnienia wyraźnych dysproporcji w zakresie wartości i struktury depozytów przypadających na mieszkańca w poszczególnych państwach, identyfikując jednak względnie jednorodne ich podgrupy, takie jak: Belgia i Holandia, Francja i Niemcy czy Słowacja i Słowenia. Grupowanie wskazało także na występowanie krajów o ukierunkowanych zmianach w depozytach, które przynależały do różnych podzbiorów w poszczególnych latach oraz na utrzymującą się odrębność Luksemburga. Pominięcie dysproporcji w wielkości populacji i przeprowadzenie analizy kształtowania się struktury zagregowanej wartości depozytów gospodarstw domowych w grupie ukazało nierówny dostęp MIF z poszczególnych krajów do funduszy uznanych przez regulatora za stabilne. W pracy potwierdzono także różne preferencje społeczeństw w zakresie terminu, na jaki dokonywano lokat w zmieniającym się otoczeniu. Dowiedziono również występowania statystycznie istotnych różnic w kształtowaniu się poziomu depozytów gospodarstw domowych w MIF w podokresach: P1, P2, P3 i P4, które cechowały się odmiennymi warunkami panującymi na rynku finansowym i w gospodarkach narodowych. 
Otrzymane wyniki skłaniają do stwierdzenia, że w latach 2006-2012 wystąpiły istotne zmiany w zakresie wartości oraz struktury depozytów w 16 państwach członkowskich strefy euro. Aby zapewnić skuteczność przyjętych wspólnych rozwiązań płynnościowych, wskazane jest zatem pozostawienie narodowym władzom nadzorczym możliwości ich modyfikowania w zakresie określania poziomu lokalnych stóp odpływu dla depozytów gospodarstw domowych w instytucjach kredytowych.

\section{Literatura}

Dyrektywa Parlamentu Europejskiego i Rady 2013/36/UE z dnia 26 czerwca 2013 r. w sprawie warunków dopuszczenia instytucji kredytowych do działalności oraz nadzoru ostrożnościowego nad instytucjami kredytowymi i firmami inwestycyjnymi, zmieniająca dyrektywę 2002/87/WE i uchylająca dyrektywę 2006/48/WE oraz 2006/49/WE, Dz.Urz. UE L 176, 27.06.2013.

Maddala G.S. [2007], Ekonometria, Wydawnictwo Naukowe PWN, Warszawa.

Pociecha J., Podolec B., Sokołowski A., Zając K. [1988], Metody taksonomiczne w badaniach społeczno-ekonomicznych, PWN, Warszawa.

Rozporządzenie Parlamentu Europejskiego i Rady (UE) nr 575/2013 z dnia 26 czerwca 2013 r. w sprawie wymogów ostrożnościowych dla instytucji kredytowych i firm inwestycyjnych, zmieniające rozporządzenie (UE) nr 648/2012, Dz.Urz. UE L 176, 27.06.2013.

Statystyka ogólna [2004], red. M. Woźniak, Uniwersytet Ekonomiczny w Krakowie, Kraków.

\section{The Role of Household Deposits in Funding the Stability of Credit Institutions in the Eurozone}

The paper presents the results of empirical research on the stability of household deposits lodged in the monetary financial institutions (MFIs) of euro area member states in the period 2006-2012. Its aim is to assess the effectiveness of liquidity regulations based on the common European standards (norms: LCR and NSFR). The paper presents the differences in the ability of the countries to accumulate the deposits which, in the opinion of the supervisory authorities, can guarantee the funding stability of the analysed entities under both normal and stressed conditions. It reveals geographical variations in household preferences regarding the duration and value of invested resources and also shows the diversity in the impact of the stages of the financial crisis on the changes in the value of the deposits taken by the Eurozone's MFIs.

Keywords: household deposits, retail deposits, credit institutions, monetary credit institutions, liquidity norms, LCR, NSFR. 